\title{
Role of Different Levels of Nitrogen, Phosphorus and Potassium on Growth, Yield and Quality Attributes of Bitter Gourd (Momordica charantia L.)
}

\author{
Irfan Ashraf ${ }^{1}$, Muhammad Zain ${ }^{1}$, Mubeen Sarwar ${ }^{2, *}$, Karim Y. Abbasi ${ }^{1}$, Mubashir Amin ${ }^{1}$ \\ ${ }^{1}$ Institute of Horticultural Sciences, University of Agriculture Faisalabad, Pakistan \\ ${ }^{2}$ Institute of Agricultural Sciences, University of the Punjab Lahore, Pakistan
}

Copyright $\bigcirc 2019$ by authors, all rights reserved. Authors agree that this article remains permanently open access under the terms of the Creative Commons Attribution License 4.0 International License

\begin{abstract}
Bitter gourd is an important crop in Pakistan. Bitter gourd has a lot of dietary and medicinal importance. In Pakistan, there is a tremendous potential for using the inorganic fertilizer, but unfortunately adequate amount of fertilizer regarding the bitter gourd crop are lacking. The experiment was studied at the Vegetable Research Area, Institute of Horticultural Sciences, University of Agriculture, Faisalabad during the year 2014-2015, to see the efficacy of inorganic fertilizers on vegetative and reproductive attributes of bitter gourd. Faisalabad Long variety of bitter gourd was used. The experiment was laid out according to Randomized Complete Block Design consisting of six treatments with four replications. The response of vegetative parameters like growth, yield and quality were recorded and analyzed statistically at the $5 \%$ level of significance. Different doses of inorganic fertilizers showed variations among, germination, fruit, fresh weight, fruit diameter and chemical parameter like vitamin $\mathrm{C}, \mathrm{pH}$ and phenolic compound of fruit. This experiment showed that treatment $\left(\mathrm{T}_{4}\right) \mathrm{N}$ : P: K $(250,100,80$ $\mathrm{kg} / \mathrm{ha}$ ) gave more fresh and dry weight of the fruit and Vitamin C. Treatment $\left(T_{5}\right)$ N: P : K $(300,120,100 \mathrm{~kg} / \mathrm{ha})$ showed increased the vegetative growth, vine length, number of leaves but showed least reproductive phase. It is concluded that dose of nitrogen $(250 \mathrm{~kg} / \mathrm{ha})$ and adequate amount of potassium $(100 \mathrm{~kg} / \mathrm{ha})$ along with phosphorus $(80 \mathrm{~kg} / \mathrm{ha})$ fertilizers increase the vegetative growth as well as reproductive growth.
\end{abstract}

Keywords Bitter Gourd, Fertilizer, Fruit Quality

\section{Introduction}

Bitter gourd (Momordica charantia) is a creeper that mainly cultivated in China, India, Pakistan, Central America, East America and South America (Nadkarni,
2000).

In Pakistan, India, Vietnam, Thailand and Nepal bitter gourd are grown in highest in the world. The largest producer of bitter gourd is India that produces $31 \%$ of the total world's production while China produces $22 \%$ and Pakistan $9 \%$ of the world production of bitter gourd. In 2012-13, the average yield of bitter gourd was 14 tons /hectare in Pakistan. Among all provinces, Punjab has the highest yield (15tonnes/ hectare). In the Punjab total area under cultivation of bitter gourd was 4299 hectares with production of 49781 tonnes (GOP, 2013).

Son (2002) concluded in bitter gourd that potassium and nitrogen affect more than that of phosphorus to the number of fruit and also to the fresh and dry weight of fruits and the mixture of high dose of nitrogen along with potassium has less effect on number of fruit but if we add them separately in higher amount then they have a great effect. Akhter et al. (2009) stated that potassium element is very important for the metabolism of plant and also for more production of carbohydrates in bitter gourd. Adequate uses of inorganic and organic fertilizers is very important for getting good yield and quality, enhance of the crop also improve the soil environmental and health conditions (Rani and Mallareddy., 2007). However, there is a basic constraint in handling organic fertilizers due to their balkiness and slowly available nutrient compared to chemical fertilizers (Hailu et al., 2007). Shalaby et al. (1997) reported that nitrogen and potassium have an inverse relationship. If we increase one of them, then other is decreased. If we apply both in high or less amount the resulting decrease the production. Nitrogen ranking as fertilizer in the eyes of scientist is higher than other nutrient in bitter gourd quality enhancement. (Hochmuth et al., 2006; Nikolova et al., 1999) found that due to the instant accessibility of nitrogen to the plants that use of inorganic fertilizer by the farmers is common. But the ecosystem and environment is damaged by using fertilizers continuously. Adequate supply of $\mathrm{N}$ to 
crops is fundamental to optimize crop yields, but the mismanagement of nitrogen, such as excessive $\mathrm{N}$ application can result in contamination of groundwater (Jaynes et al., 2001). Potassium is an important element in plant metabolism, promoting carbohydrate synthesis (Shalaby et al., 1997)

\section{Materials and Mehtods}

Present experiment was conducted on the area of $=6 \times 16=96 \mathrm{ft}^{2}$ at vegetable experimental and research area, institute of Horticultural Sciences, University of Agriculture, Faisalabad, during the year 2014-15. The experiment was laid out according to Randomized Complete Block Design (RCBD). The seeds of bitter gourd were parched from seed market Dajkot road, Faisalabad. Bitter gourd variety Faisalabad long was selected for research. Six treatments of NPK are with different concentration with four replications. One third nitrogen was applied at the time of seedbed preparation, One third after one month and remaining after two months. Whole of the phosphorus was applied at the time of seed bed preparation. Half of the potassium was applied at the time of seed bed preparation and half of the potassium after one month of sowing. Seed was sown on raised beds. Application of $184 \mathrm{~kg} \mathrm{~N}, 112 \mathrm{~kg}$ P2O5, and $124 \mathrm{~kg} \mathrm{~K} 2 \mathrm{O} / \mathrm{ha}$ gave a significant yield of bitter gourd (Palama and Chang, 2003).

\section{The following treatments were studied:}

$\mathrm{T}_{0}=$ Control, $\mathrm{T}_{1}=\mathrm{N}: \mathrm{P}: \mathrm{K}(100: 40: 20) \mathrm{kg} / \mathrm{ha}, \mathrm{T}_{2}=\mathrm{N}:$ $\mathrm{P}: \mathrm{K}(150: 60: 40) \mathrm{kg} / \mathrm{ha}, \mathrm{T}_{3}=\mathrm{N}: \mathrm{P}: \mathrm{K}(200: 80: 60)$ $\mathrm{kg} / \mathrm{ha}, \mathrm{T}_{4}=\mathrm{N}: \mathrm{P}: \mathrm{K}(250: 100: 80) \mathrm{kg} / \mathrm{ha}, \mathrm{T}_{5}=\mathrm{N}: \mathrm{P}: \mathrm{K}$ $(300: 120: 100) \mathrm{kg} / \mathrm{ha}$

\section{Results and Discussion}

Present research studies were carried out at Vegetable Research Area, University of Agriculture, Faisalabad, during 2014 to ascertain the role of different levels of NPK fertilizers on growth, yield and quality attributes of bitter gourd. The results of studies pertaining germination \%, number of days to first flowering, number of days to first harvesting, fruit diameter, fruit length, fruit weight, Fruit dry weight, number of fruit per vine, yield per plant, yield per ha, number of seed per fruit, seed yield per ha, number of leaves per vine, chlorophyll content and chemical parameters likes vitamin $\mathrm{C}$, phenolic content and $\mathrm{ph}$ of fruits are given below

\section{Final Germination Percentage (\%)}

Bitter gourd (Faisalabad long) was revealed under experiment and germination \% was noted. It is clear that different levels of fertilizers showed to significant change in germination percentage (\%). Tablel showed the comparison of germination percentage of Faisalabad long by different levels of NPK fertilizers treatments. Maximum germination \% was recorder by treatment (N:P:K 250:100:80 ) with an average of 83.50 , followed by treatment (N:P:K 200:80:60). Minimum germination \% was observed in (control) with an average of 63.75 .

Premsekhar and Rajashree (2009) worked on tomato and reported that growth parameters of tomato differ significantly with different levels of NPK fertilizers.

\section{Number of Days Taken to First Flowering}

Results showed that different levels of fertilizers showed significant difference in number of days taken to first flowering. Table 1 showed the comparison of number of days taken to first flowering of Faisalabad long variety gained by different levels of NPK fertilizers treatments. Maximum number of days taken to first flowering was recorded in (N:P:K 300,120,100) with an average of 50.250 days, followed by (control) with 45.50. Minimum number of days taken to first flowering was recorded as (N:P:K 250:100:80 ) with 39 days.

The result are correlated with Harris et al. (2007) who reported that potassium causes the earlier flowers in rice and increased the yield. Murunge et al., (2004) reported that reduce the number of days of flowering by using fertilizers and seed priming.

Table 1. Role of different levels of Nitrogen, Phosphorus and Potassium on germination \%, Days to flowering, fruit diameter, fruit length and days taken to harvest of bitter gourd (Momordica charantia L.).

\begin{tabular}{|c|c|c|c|c|c|}
\hline Treatment & Germination\% & $\begin{array}{c}\text { Days to } \\
\text { flowering }\end{array}$ & Fruit Diameter (cm) & Fruit Length (cm) & $\begin{array}{c}\text { Days taken } \\
\text { to first harvest }\end{array}$ \\
\hline Control & $63.750 \mathrm{f}$ & $45.50 \mathrm{~b}$ & $3.59 \mathrm{~d}$ & $66.75 \mathrm{~b}$ \\
\hline$\left(\mathrm{N}: \mathrm{P}: \mathrm{K} 100: 40: 20 \mathrm{~kg} \mathrm{ha}^{-1}\right)$ & $67.75 \mathrm{e}$ & $45.25 \mathrm{~b}$ & $3.77 \mathrm{~d}$ & $13.72 \mathrm{~cd}$ & $65.75 \mathrm{~b}$ \\
\hline$\left(\mathrm{N}: \mathrm{P}: \mathrm{K} 150: 60: 40 \mathrm{~kg} \mathrm{ha}^{-1}\right)$ & $72.25 \mathrm{~d}$ & $42.25 \mathrm{c}$ & $4.06 \mathrm{c}$ & $14.46 \mathrm{c}$ \\
\hline$\left(\mathrm{N}: \mathrm{P}: \mathrm{K} 200: 80: 60 \mathrm{~kg} \mathrm{ha}^{-1}\right)$ & $75.25 \mathrm{c}$ & $41.0 \mathrm{c}$ & $4.51 \mathrm{~b}$ & $16.65 \mathrm{~b}$ & $65.50 \mathrm{~b}$ \\
\hline$\left(\mathrm{N}: \mathrm{P}: \mathrm{K} 250: 100: 80 \mathrm{~kg} \mathrm{ha}^{-1}\right)$ & $83.50 \mathrm{a}$ & $39.0 \mathrm{~d}$ & $4.87 \mathrm{a}$ & $19.37 \mathrm{a}$ & $16.65 \mathrm{~b}$ \\
\hline$\left(\mathrm{N}: \mathrm{P}: \mathrm{K} 300: 120: 100 \mathrm{~kg} \mathrm{ha}^{-1}\right)$ & $78.50 \mathrm{~b}$ & $50.25 \mathrm{a}$ & $4.47 \mathrm{~b}$ & $72.75 \mathrm{a}$ \\
\hline
\end{tabular}




\section{Fruit Diameter (cm)}

It is clear from the Results that different levels of fertilizers showed significant difference in diameter of the fruits. Maximum diameter of the fruit was recorded in (N:P:K 250:100:80) which is of $4.87 \mathrm{~cm}$, followed by $(\mathrm{N}: \mathrm{P}: \mathrm{K}$ 300:120:100 ). Minimum diameter of the fruit was in (control) 3.59 .

Our results are matching with Nasreen et al., (2013). Mulani et al., (2007) reported that nitrogen and bio fertilizer increase the diameter of the fruits.

\section{Fruit Length (cm)}

Maximum fruit length was recorded in (N:P:K 250:100:80) which is of $19.375 \mathrm{~cm}$, followed by $(200,80,60)$ which is $16.650 \mathrm{~cm}$. Minimum fruits length was recorded as (control) which is $12.903 \mathrm{~cm}$.

Our results are matching with Gengaihi (2005) who stated that bitter gourd fruit length is increased by potassium and nitrogen.

\section{Fruit Fresh Weight (g)}

Table 2 showed the comparison of fruit weight of Faisalabad long variety gained by different levels of NPK fertilizers treatments. Maximum fruit weight were recorded in (N:P:K 250:100:80) which is $95.05 \mathrm{~cm}$, followed by (N:P:K 200:80:60). Minimum fruit weight was recorded in (control) which is 61.15.

Results are in line with the finding of El-Gengaihi et al. (2005) reported that due to nitrogen and potassium fresh fruit weight increasing in bitter gourd. Abd-El-Baky (2010) stated that potassium and nitrogen increased the weight in sweet potato.

Besford et al., (1975) stated that due to potassium tomato fresh weight increases.

\section{Fruit Dry Weight (g)}

Maximum fruit dry weight were recorded in $(\mathrm{N}: \mathrm{P}: \mathrm{K}$
250:100:80) which is $12.25 \mathrm{~g}$, followed by (NPK 200:80:60) . Minimum fruit dry weight was recorded as (control) which is $7.70 \mathrm{~g}$.

Results are in line with the finding of Nasreen et al. (2013). Results are in line with the finding of El-Gengaihi et al., (2005) reported that due to nitrogen and potassium fruit dry weight increasing in bitter gourd.

\section{Number of Fruit per Vine}

Maximum number of fruit per vine were recorded in (N:P:K 250:100:80) with an average of 18.25 , followed by (NPK 200,80,60) with 16 number of fruit. Minimum number of fruits per vine was recorded as $\mathrm{T}_{0}$ (control) which is 9.50 .

Result is matching with the Palada et al., (2003) who stated that nitrogen increased the number of fruits.

\section{Fruit Yield per Vine (kg)}

Maximum fruit yield per vine were recorded in (N:P:K 250:120:100) with an average of $2.04 \mathrm{~kg}$, followed by $(\mathrm{N}: \mathrm{P}: \mathrm{K}$ 200:80:60) which is $1.58 \mathrm{~kg}$. Minimum fruit yield per vine was recorded as (control) which is 0.5765 .

Result is matching with the Palada et al. (2003) who stated that nitrogen increased the yield of bitter gourd. Belokar et al. (1992) stated that nitrogen increased the flowering as well fruit yield.

\section{Fruit Yield per Hectare (Tons)}

Table 2 showed the comparison of fruit yield per vine of (Faisalabad long) variety gained by different levels of fertilizer treatments. Maximum fruit yield per hectare were recorded in (N:P:K 250:100:80) with an average of 29.27 tons, followed by (N:P:K 200:80:60) which is 22.77 tons. Minimum fruit yield per hectare was recorded as (control) which is 8.28 tons.

Our results are in accordingly to Palada et al. (2003). Bidari et al. (2011) and El- Desuki et al. (2005) stated that potassium and nitrogen increased the yield in raddish.

Table 2. Role of different levels of Nitrogen, Phosphorus and Potassium on fruit fresh and dry weight, number of fruit vine ${ }^{-1}$, fruit yield vine ${ }^{-1}$, fruit yield hec ${ }^{-1}$ of bitter gourd (Momordica charantia L.).

\begin{tabular}{|c|c|c|c|c|}
\hline Treatment & $\begin{array}{c}\text { Fruit } \\
\text { weight(g) }\end{array}$ & $\begin{array}{c}\text { Fruit dry } \\
\text { weight }(\mathrm{g})\end{array}$ & $\begin{array}{l}\text { Number of } \\
\text { fruit vine }^{-1}\end{array}$ & $\begin{array}{l}\text { Fruit yield fruit yield } \\
\operatorname{vine}^{-1}(\mathrm{~kg}) \text { per hectare }\end{array}$ \\
\hline (control) & $61.15 \mathrm{~d}$ & $7.70 \mathrm{~d}$ & $9.50 \mathrm{e}$ & 0.576 e $8.28 \mathrm{e}$ \\
\hline$\left(\mathrm{N}: \mathrm{P}: \mathrm{K} 100: 40: 20 \mathrm{~kg} \mathrm{ha}^{-1}\right)$ & $77.40 \mathrm{c}$ & $9.45 \mathrm{c}$ & $12.00 \mathrm{~d}$ & $0.930 \mathrm{~d} 13.34 \mathrm{~d}$ \\
\hline (N:P:K 150:60:40 kg ha' $\left.{ }^{-1}\right)$ & $78.05 \mathrm{c}$ & $10.13 \mathrm{bc}$ & $13.75 \mathrm{c}$ & $1.073 \mathrm{c} 15.39 \mathrm{~cd}$ \\
\hline (N:P:K 200:80:60 kg ha $\left.{ }^{-1}\right)$ & $87.12 \mathrm{~b}$ & $11.86 \mathrm{a}$ & $18.10 \mathrm{~b}$ & $1.587 \mathrm{~b} 22.77 \mathrm{~b}$ \\
\hline (N:P:K 250:100:80 kg ha-1) & $95.05 \mathrm{a}$ & $12.35 \mathrm{a}$ & $22.25 \mathrm{a}$ & $2.041 \mathrm{a} 29.27 \mathrm{a}$ \\
\hline (N:P:K 300:120:100 $\mathrm{kg} \mathrm{ha}^{-1}$ ) & $86.30 \mathrm{~b}$ & $11.09 \mathrm{ab}$ & $16.00 \mathrm{~b}$ & $1.204 \mathrm{c} 17.10 \mathrm{c}$ \\
\hline
\end{tabular}




\section{Number of Leaves per Vine}

Maximum number of leaves per vine were recorded in $(\mathrm{N}: \mathrm{P}: \mathrm{K} 300: 120: 100)$ with an average of 124, followed by $(\mathrm{N}: \mathrm{P}: \mathrm{K} 250: 100: 80)$ which is 103.50 . Minimum number of leave per vine was recorded as (control) which is 78.75 .

Our results are matching with Nasreen et al., (2013). She stated that due to high amount of nitrogen the number of leaves increased. Aghassbasi (2012) stated that due to organic and inorganic chemicals the number of leaves increased in bitter gourd.

\section{Final Vine Length (cm)}

Maximum final vine length was recorded in $(\mathrm{N}: \mathrm{P}: \mathrm{K}$ $300: 120: 100)$ with an average $316.50 \mathrm{~cm}$, followed by $(\mathrm{N}: \mathrm{P}: \mathrm{K} 250: 100: 80)$ with $295.95 \mathrm{~cm}$. Minimum final vine length was recorded as (Control) which is $243.13 \mathrm{~cm}$.

Our results are matching with palada et al. (2003). Aghassbasi (2012) stated that due to organic and inorganic chemicals the vine length increased in bitter gourd.

\section{Number of Seed per Fruit}

Maximum number of seed per fruit were recorded in (N:P:K 250:100:80) with an average of 24.20, followed by $\mathrm{T}_{3}$ (N:P:K 200:80:60) which is 23.50. Minimum diameter $3.4 \mathrm{~cm}$ of fruits was recorded as $\mathrm{T}_{0}$ (control) which is 16.875 .

Results are similar to Aruna et al., (2012). Ahmad et al., (2011) stated that due to nitrogen the seed yield increased in canola. Hossain et al. (2009) stated that due to nitrogen the seed yield increased in carrot.

\section{Seed Yield per Hectare (kg)}

Maximum seed yield per hectare were recorded in $(\mathrm{N}: \mathrm{P}: \mathrm{K} 250: 100: 80)$ with an average of $522.27 \mathrm{~kg}$, followed by (N:P:K 200:80:60) which is $456.27 \mathrm{~kg}$. Minimum seed yield per hectare $\mathrm{T}_{0}$ (control) was recorded as T0 $270.46 \mathrm{~kg}$.

Results are similar to Aruna et al. (2012). Ahmad et al. (2011) stated that due to nitrogen the seed yield increased in canola. Hossain et al., (2009) stated that due to nitrogen the seed yield increased in carrot.

\section{Seed Weight $(g)$}

Table 3 showed the comparison of average 1000 seed weight of Faisalabad long variety gained by different levels of fertilizers treatments. Maximum1000 seed was recorded in (N:P:K 250:100: 80) with an average of 142.5, followed by (N:P:K 200:80:60) 142.15. Minimum seed yield per hectare $\mathrm{T}_{0}$ (control) was recorded in which is $134.88 \mathrm{~g}$.

Results are similar to Aruna et al. (2012) who stated that nitrogen increased the 1000 seed weight in bitter gourd.

\section{Chlorophyll Content}

Table 4 showed the comparison of average chlorophyll content of Faisalabad long variety gained by different levels of fertilizers treatments. Maximum chlorophyll content were recorded in (N:P:K 300:120:100) with an average of 21.94 , followed by (N:P:K 250:100:80) 20.1 . Minimum chlorophyll content was recorded as (control) 13.5 .

These results are in the agreement with the findings of Sonu and Singh (2005) who reported that maximum chlorophyll content when $100 \mathrm{~kg}$ potassium was applied.

Nitrogen is the involved in the synthesis of bio molecules in plant such as amino acid and nucleic acid and pigments. Chlorophyll content was reported that it is correlated with the amount of nitrogen .moreover nitrogen application to nitrogen deficient soils transcripts levels of nicotianamine synthesis gene which is directly related to chlorophyll synthesis pich et al., (2001). Chlorophyll content is more when the amount of nitrogen is more these are not correlated with the amount of potassium and phosphorus.

Table 3. Role of different levels of Nitrogen, Phosphorus and Potassium on no. of leaves per vine, length of vine, no. of seed per fruit, seed yield hec ${ }^{-1}$, 1000 seed weight of bitter gourd (Momordica charantia L.)

\begin{tabular}{|c|c|c|c|c|c|}
\hline Treatment & $\begin{array}{c}\text { number of leaves } \\
\text { per vine }\end{array}$ & $\begin{array}{c}\text { Final vine } \\
\text { length }\end{array}$ & $\begin{array}{c}\text { number of } \\
\text { seed per fruit }\end{array}$ & $\begin{array}{l}\text { Seed yield } \\
\text { per hectare }\end{array}$ & 1000 seed weight \\
\hline (control) & $78.75 \mathrm{e}$ & $243.13 \mathrm{f}$ & $16.87 \mathrm{~d}$ & $270.46 \mathrm{f}$ & $134.88 \mathrm{~b}$ \\
\hline$\left(\mathrm{N}: \mathrm{P}: \mathrm{K} 100: 40: 20 \mathrm{~kg} \mathrm{ha}^{-1}\right)$ & $86.50 \mathrm{~d}$ & $260.60 \mathrm{e}$ & $18.50 \mathrm{~cd}$ & $334.67 \mathrm{e}$ & $140.38 \mathrm{a}$ \\
\hline (N:P:K 150:60:40 $\left.\mathrm{kg} \mathrm{ha}^{-1}\right)$ & $91.00 \mathrm{~cd}$ & $274.85 \mathrm{~d}$ & $20.00 \mathrm{bc}$ & $377.00 \mathrm{~d}$ & $141.25 \mathrm{a}$ \\
\hline$\left(\mathrm{N}: \mathrm{P}: \mathrm{K} 200: 80: 60 \mathrm{~kg} \mathrm{ha}^{-1}\right)$ & $95.75 \mathrm{c}$ & $283.12 \mathrm{c}$ & $23.50 \mathrm{a}$ & $456.27 \mathrm{~b}$ & $142.15 \mathrm{a}$ \\
\hline$\left(\mathrm{N}: \mathrm{P}: \mathrm{K} 250: 100: 80 \mathrm{~kg} \mathrm{ha}^{-1}\right)$ & $103.50 \mathrm{~b}$ & $295.95 \mathrm{~b}$ & $24.25 \mathrm{a}$ & $522.27 \mathrm{a}$ & $142.25 \mathrm{a}$ \\
\hline$\left(\mathrm{N}: \mathrm{P}: \mathrm{K} 300: 120: 100 \mathrm{~kg} \mathrm{ha}^{-1}\right)$ & $124.00 \mathrm{a}$ & $316.50 \mathrm{a}$ & $21.50 \mathrm{~b}$ & $401.75 \mathrm{c}$ & $142.00 \mathrm{a}$ \\
\hline
\end{tabular}

Table 4. Role of different levels of Nitrogen, Phosphorus and Potassium on chemical parameter of bitter gourd (Momordica charantia L.)

\begin{tabular}{|c|c|c|c|c|}
\hline Treatment & chlorophyll content & vitamin $\mathrm{C} \mathrm{mg} / 100 \mathrm{~g}$ & $\mathrm{pH}$ & Phenolic compound CAE/ mg \\
\hline (control) & $14.07 \mathrm{f}$ & $82.62 \mathrm{~d}$ & $5.25 \mathrm{f}$ & $5.07 \mathrm{a}$ \\
\hline (N:P:K 100:40:20 kg ha ${ }^{-1}$ ) & $19.65 \mathrm{e}$ & $84.60 \mathrm{c}$ & $5.27 \mathrm{e}$ & $5.05 \mathrm{a}$ \\
\hline$\left(\mathrm{N}: \mathrm{P}: \mathrm{K} 150: 60: 40 \mathrm{~kg} \mathrm{ha}^{-1}\right)$ & $22.65 \mathrm{~d}$ & $85.15 \mathrm{bc}$ & $5.45 \mathrm{~d}$ & $5.28 \mathrm{a}$ \\
\hline$\left(\mathrm{N}: \mathrm{P}: \mathrm{K} 200: 80: 60 \mathrm{~kg} \mathrm{ha}^{-1}\right)$ & $125.05 \mathrm{c}$ & $86.72 \mathrm{~b}$ & $5.62 \mathrm{c}$ & $4.26 \mathrm{a}$ \\
\hline$\left(\mathrm{N}: \mathrm{P}: \mathrm{K} 250: 100: 80 \mathrm{~kg} \mathrm{ha}^{-1}\right)$ & $27.32 \mathrm{~b}$ & $89.40 \mathrm{a}$ & $5.82 \mathrm{~b}$ & $4.52 \mathrm{a}$ \\
\hline$\left(\mathrm{N}: \mathrm{P}: \mathrm{K} 300: 120: 100 \mathrm{~kg} \mathrm{ha}^{-1}\right)$ & $29.32 \mathrm{a}$ & $85.05 \mathrm{bc}$ & $5.95 \mathrm{a}$ & $4.57 \mathrm{a}$ \\
\hline
\end{tabular}




\section{Vitamin C mg /100g}

Maximum vitamin $\mathrm{C}$ were recorded in $(\mathrm{N}: \mathrm{P}: \mathrm{K}$ 250:100:80) with an average of $89.40 \mathrm{mg} / 100 \mathrm{~g}$, followed by (N:P:K 200:80:60) which is $86.72 \mathrm{mg} / 100 \mathrm{~g}$. Minimum vitamin $\mathrm{C}$ was recorded as (control) which is 82.625 $\mathrm{mg} / 100 \mathrm{~g}$

Results are in agreement with the finding of (Akhter et al., 2009). The results showed that by applying the adequate amount of fertilizers the highest amount of vitamin $\mathrm{C}$ obtained. Results are also in line with Nasreen et al. (2013).

\section{pH of Fruit}

Maximum ph of the fruit were recorded in (N:P:K $300: 120: 100)$ with an average of 5.95 , followed by (N:P:K 250:100:80) which is 5.82. Minimum ph of fruit was recorded as (control) which is 5.2.

These results showed that highest levels of nitrogen $300 \mathrm{~kg} / \mathrm{ha}$ along with $120 \mathrm{~kg} /$ ha potassium gave maximum results.

\section{Phenolic Compound CAE/ mg}

Maximum phenolic compound was recorded in $(\mathrm{N}: \mathrm{P}: \mathrm{K}$ 150:60:40) with an average of 5.2875 GAE/mg, followed by (control) which is $5.0750 \mathrm{GAE} / \mathrm{mg}$. Minimum phenolic compound was recorded as (N:P:K 200:8:60) which is 4.2625 GAE $/ \mathrm{mg}$.

Kim et al. (2003) and Lee et al. (2003) reported that phenolic compound is different within the same variety it is not depend upon fertilizers. The variation among same or different varieties is due to some environmental factors such as heat availability of water. Phenolic compound highly depend on water (Lee et al., 2003).

\section{REFERENCES}

[1] Abd El-Baky MMH, Ahmed A A, M A. El-Nemr and Zaki MF (2010). Effect of potassium fertilizer and foliar zinc application on yield and quality of sweet potato. Research Journal of Agriculture and Biological Sciences. 6(4): 386-394.

[2] Aghaabasi K and Baghizadeh A (2012). Effect of inorganic and organic fertilizers on bitter gourd quality. Afr. J. Biotechnol. 11:10056-10062.

[3] Ahmad G, Jan A, Arif M, Jan M T and Shah H (2011). Effect of nitrogen and sulfur fertilization on yield components, seed and oil yields of canola. J. Plant Nutri.

[4] Akhter L, Islam M. S, Uddin M N and Ahmed S (2009). Evaluation of New Bitter Gourd Germplasum. Research Report, 2008-2009. Horticulture Research Centre, BARI, Gazipur.p. 16
[5] Aruna P and Swaminathan V (2012). Effect of nitrogen and Evaluation of hybrids for high yield and yield attributes in bitter gourd (Momordica charantia L.). The Asian Journal of Horticulture 7:624-625

[6] Belokar P V, Patel B N, Golliwar V J and Kothare AJ (1992). Effect of nitrogen levels and spacing on growth, flowering and yield of African marigold. J. Soil and Crops. 2(1): 62-64.

[7] Besford R T and Maw G A (1975). Effect of potassium nutrition on tomato plant growth and fruit development. Int. J. Plant-Soil Relationships. 42: 395-412.

[8] Bidari B I and Hebsur N S. 2011. Potassium in relation to yield and quality of selected vegetable crops. Karnataka J. Agr. Sci. 24(1): 55-59.

[9] El-Gengaihi S, Karawya M S, Motaw H M, Selim M H, Ibrahim N A (2005). Nitrogen and potassium increased yield and quality of bitter gourd. Bull Natl Res Cent (Egypt). 21(3):265-8.

[10] GOP. (2013). Agriculture statistic of Pakistan 2012-2013, Ministry of Food, Agriculture, Livestock. Food, Agriculture and Livestock Division (Economic Wing), Islamabad.

[11] Hailu T C, Thorpe T and Greppin H (2007). Peroxidases 1970-1980. A survey of their biochemical and physiological roles in higher plants. Universite de Geneve, Centre de Botanique. 889-1112.

[12] Harris G S, Rao P V, Reddy Y N and Reddy MS (2007). Effect of nitrogen and potassium levels on yield and nutrient uptake in paprika (Capsicum annum L.) under irrigated conditions of northern Telangana zone of Andhra Pradesh. The Asian J. Hort. 2(1): 193-196.

[13] Hochmuth F, Darvishzadeh R, Hassani A and Hassanzaeh A (2006). Study on genetic variation in Iranian castor bean (Ricinus communis L.) accessions using multivariate statistical techniques.Government of Pakistan. 2014. Fruit, vegetables and condiments statistics of Pakistan.

[14] Hossain AKMM, Islam M R, Bari M. S, Amin MHA and Kabir M.A (2009). Effect of mulching and levels of potassium on growth and yield of carrot. Bangladesh Research Pub. J. 3(2): 963-970.

[15] Jaynes D B, Colvin T S, Karlen D L, Cambardella C A, Meek D W (2001). Nitrate loss in subsurface drainage as affected by nitrogen fertilizer rate. J. Environ. Qual. 30, 1305-1314.

[16] Kim D O, Jeong S J and Lee C V (2003). Antioxident capacity of phenolic compounds in plums. Food chem. 81:321-6.

[17] Mulani S A, Hussain A, Rab and Wadan D (2007).Effect of phosphorus levels and sowing dates on the growth and production of bitter gourd. Department of Horticulture, NWFP Agricultural University, Peshawar, Pakistan. Sarhad J. Agric. 21:591-594.

[18] Murungu F S and Chiduza C (2004). Effect of fertilizers and seed priming on emergence, flowering and yield of cotton and maize in Zimbabaw. Exp. 40: 23-36.

[19] Nadkarni A K (2000). Indian Meteria Medica. Publ. Popular Prakashan PVT. Ltd., Bombay. 1: 805-7. 
[20] Nasreen S, Ahmad R and Nazim M (2013). NPK and S for yield maximization of bitter gourd. ISSN 0258-7122. Bangladesh J. Agril. 38(2): 355-361.

[21] Nikolova A, Kozhuharova K, Zheljazkov VD, Crakere LE, Giberti G (1999). Mineral neutrition of chamomille. Proceedings of the Second World Congress on Medicinal and Aromatic Plants for Human Welfare. Acta Hort; 502:203-8.

[22] Palada M C and Chang L. C (2003). Suggested cultural practices for bitter gourd. AVRJJC Pandey, U.B., and L. Singh. 2001. Export of vegetables, pp. 321-332.

[23] Pich D H and Hall, C B (2001). Fe hemostatsis in plant regulation of cytoplasmic $\mathrm{Fe}$ concentraction. Planta. 213:967.

[24] Premsekhar-Rajashree S (2009). Associations among Morphological and Phonological Characters Representing by phosphorus and potassium. J. Amer. Soc. Hort. Sci. 117:486-490.

[25] Rani, K. R. and A. Mallareddy (2007). Performance of bitter gourd genotypes for yield and earliness. J. Plan. Soil Res. 16:330-333.

[26] Son Y (2002). Effect of nitrogen fertilization on foliar nutrient dynamics in Ginkgo seedlings. J. Nutrition; 25(1):93-102. 